\title{
The Difficulties and Possibilities of E-Government: The Case of Jordan
}

\author{
Rifat O. Shannak \\ Associate Professor of Management Information Systems \\ Faculty of Business, University of Jordan, Amman, Jordan \\ E-mail: rshannak@ju.edu.jo
}

Received: October 24, 2012

Accepted: February 27, 2013 Published: April 1, 2013

doi:10.5296/jmr.v5i2.2560

URL: http://dx.doi.org/10.5296/jmr.v5i2.2560

\begin{abstract}
The purpose of this paper is to explore the realities of the e-government as well as to examine the challenges and complexities of its implementation in the context of Jordanian society.

A brief analysis of Jordanian published e-government vision and strategy is presented together with a review of relevant literature as related to national and international reports as well as some working papers. A number of interviews and focus groups were carried out and relevant data analyses were performed. Finally, the paper highlights the potential challenges facing the implementation of e-Government and presents a proposal for further empirical research in the form of a comprehensive research project requiring hard data collection through the suggested instruments.
\end{abstract}

Keywords: E-Government, ICT, Challenges, Jordan, E-Government vision, E-Government Strategy 


\section{Introduction}

In the current era, the world has witnessed a revolution in information and communication technologies (ICTs) that resulted in technological advancement. These advancements were introduced into the private and public sectors as a new kind of rationalization using modern information and communication technologies.

Increasingly, the use of ICT tools and applications are leading to transformational shifts in public policy, processes and functions. E-government is being deployed not only to provide citizen services but for public sector efficiency purposes allowing for cost savings in government administration and for improving transparency and accountability in government functions. ICTs are changing the way the government does business for the people (UN e-Government Survey, 2008).

Generally, e-government is considered as a new and emerging area of interest in the field e-business that employs ICTs to enhance the access to and delivery of government information and services to citizens, businesses, government employees, and other agencies. (Elsheikh et al., 2008).

The United Nations e-Government Survey of the year 2010 indicates that citizens are benefiting from more advanced e-service delivery, better access to information, more efficient government management and improved interactions with governments. This is primarily a result of the increasing use of information and communications technology by the public sector. Most countries have published tremendous amount of information online, many going beyond basic websites to provide national portals that serve as major starting points for users to connect to government services in different ministries. At the same time, many developing countries need to devote additional efforts to transactional services as well as the electronic means of engaging citizens in public consultation and decision-making.

In Jordan, as one of the developing countries, the e-Government program was a national initiative presented by his Majesty King Abdullah II. The program seeks to achieve greater efficiency in government performance by raising the level of service delivery to citizens and investors from all segments of the society, easily, quickly, accurately and efficiently in order to become a different type of improved performance of government employees and of government transactions (Heba et al, 2009). Despite the benefits and opportunities delivered by e-government, the program still faces many challenges.

This paper describes the status of e-government in Jordan, the ICT sector and the related services and benefits introduced. The remainder of the paper highlights the challenges and obstacles facing the implementation of the e-government program in Jordan.

\section{ICT Sector in Jordan}

According to the National ICT Strategy of Jordan 2007-2011, the Hashemite Kingdom of Jordan has taken a very aggressive stance to improve the life of its citizens. The foundation for that approach is the Jordan's National Agenda. In support of the National Agenda, int@j, the IT industry association of Jordan, facilitated the creation of this National ICT Strategy, 
demonstrating how Jordan will move forward in cultivating Information and Communications Technology (ICT) sector that serves as a major driver for overall economic growth in the Kingdom. Governments and non-governmental organizations (such as the World Bank and United Nations) worldwide have recognized the power of ICT to improve business, reduce poverty, improve public services, and encourage governmental improvements.

Jordan is well poised to build upon its strong foundation of people to cultivate growth in the ICT sector. The National ICT Strategy serves two basic goals; first, it identifies the sub-sectors that national ICT sector leadership will be best suited for growth given the environment in Jordan. Thus, the strategy poses a challenge to which the private sector in the country and internationally must respond. Second, it defines actions that the Jordanian Government must take to undertake its part in facilitating ICT sector growth. Thus, the strategy also poses a mandate to which the government must respond to execute its commitment to the sector. The government of Jordan has begun applying an e-Government program in 2002 which hunts for to advance service delivery and increase the engagement of people through the use of ICT, the "Levels of e-Government submission model" (Al-Jaghoub et al, 2010).

The National ICT Strategy defined three high-level strategic objectives to be achieved by the end of 2011, which involved increasing internet penetration in the Kingdom from the current $11 \%$ to $50 \%$ (according to latest announced figures during 2012, they show that the penetration is very close to the target), raising the number of workers in the ICT industry from 16,000 to 35,000 , and increasing the ICT sector's revenue to \$3 billion. The Strategy also focuses on eliminating regulatory challenges to business and advocating the interest of ICT companies to ensure continued sector growth (NAO, 2002).

Jordan faces most of the same challenges that other developing countries face in cultivating growth in the private sector and ICT industry in particular. It is thought that the growth of Jordan's ICT industry in Jordan is hampered by Government policies that are lacking in either development or, more commonly, implementation. Jordan's telecommunications services are relatively well developed - and mobile phone penetration rates are very high but lack a high rate of broadband internet access as it is still considered relatively expensive. This places PC ownership and technology utility beyond the reach of most Jordanians. Various legal and regulatory hurdles prevent the smooth operation of the market for ICT products and services.

Accordingly, in response to a challenge put forward by his Majesty King Abdullah II in 1999, the efforts were directed at devising a comprehensive framework for Jordan's ICT sector, which resulted in the REACH initiative. REACH (1999-2005) is Jordan's national blueprint for nurturing a vibrant, export-oriented, and internationally competitive ICT sector. The strategy involved developing a regulatory framework, providing an enabling infrastructural environment, and offering advancement programs, Human Resource development and capital and finance. In 2007, the National ICT Strategy (2007-2011) was launched as a continuation of the REACH initiative and encompassed a number of revised policies and directions that were aimed at taking advantage of new markets, enhancing business maturity, investing in 
research and development, capitalizing on regional demand, cultivating foreign investment, and improving the ICT labor market. (http://www.intaj.net/node/62).

The Ministry of Information and Communications Technology (MoICT) in cooperation with other Ministries, donor programs, and non-governmental organizations in Jordan, is undertaking various ICT related initiatives that aimed at:

- Increasing awareness of the benefits of using ICT.

- Improving access to technology.

- Enabling all Jordanians to partake in the Information Society.

- $\quad$ Bridging the digital gap (divide).

- Empowering local communities to use ICT for their own development.

- Assisting Jordanians in integrating ICT into their daily lives.

- Developing entrepreneurship spirit.

- Increasing youth employment in the ICT sector.

These programs were expected to lead to improved economic, cultural and social prospects for all citizens. The major initiatives of the Jordanian's national ICT sector plan are (for more details see: www.moict.gov.jo/MOICT_initiative.aspx):

1. Women in Technology Program / Jordan: The Women in Technology (WIT) program aimed at providing women in local communities with basic IT skills and professional development training as well as training on entrepreneurship skills for women who wished to start or develop their own small businesses.

2. Laptop "Notebook" for every University student: Jordan has committed itself to incorporating ICT into the daily lives of all its citizens. As part of Jordan's broader aspirations for a knowledge-based economy and society. In the educational field; Jordan has taken long strides into incorporating ICT into education. However, higher education has been slower than schools in integrating ICT and specifically the use of the Internet into its functions. Therefore, MoICT has embarked on launching an initiative entitled: "Laptop for every University Student", to be as a new prerequisite for freshman students and also the provision of connectivity (internet access), in affordable and sustainable ways (a cost no more than 15 JD per month).

3. Graduates Internship Program: The Ministry of Information and Communications Technology (MoICT) in cooperation with the Ministry of Labor and the ICT sector associations launched a Graduate Internship Program (GIP). The GIP is an 18-month employment program whereby the Government provides a subsidy of $50 \%$ of each intern's salary during the first 12 months of employment and $25 \%$ subsidy during the next six months. This program aimed at:

- Providing graduates with training and skills.

- Contributing to the relief of unemployment among graduates of information technology and telecommunications engineering.

- Contributing to the long-term economic development. 
4. Certified Courses at Jordanian Universities' Workshop: The workshop was organized in response to the Ministry of Information and Communication Technology (MoICT) having been approached by several companies to support and coordinate liaising with Jordanian universities on the issue of incorporating their IT academies or university courses into the local higher education curricula. The MoICT also hopes that by driving this process, it will be addressing one aspect of the effort to close the gap between labor market needs and IT graduates' competencies.

5. Mother and Child Program (M\&C): The Program aimed to raise awareness and introduce kindergarten-age students and their mothers to basic ICT tools and applications, with the long-term goal of increased ICT-integration into the needs of both groups and increased economic opportunities for mothers, communities, and other project participants such as interns.

6. Capacity Development of SMEs Through ICT - Shabakat Tawasol: Shabakat Tawasol was launched in September 2007, and kicked off its operations in the field by the first of Jan 2008, since then Shabakat Tawasol has enrolled 1482 beneficiaries (of which 875 are women) from the final target of beneficiaries 1536 in the first of the eight scheduled streams of the project, which till now has incubated 1433 projects. To ensure proper execution of Shabakat Tawasol, Shabakat Al Ordon enabled 40 young people including 25 females to provide around 7,720 man days to date in 21 locations across local communities in the governorates of Zarqa, Irbid, and Balqa. Shabakat Al Ordon is planning to expand Tawasol project across 12 governorates in the kingdom to train 10,000 SME's beneficiaries each year.

7. E-Village Phase II (Expansion and Replication): The "e-Village" sought to address the need to increase the capacity, awareness and economic

Opportunities of rural women in the field of information and communications technology within the villages of Lubb and Mleih (located in Madaba), as a model for bridging the country's digital divide through a gender-mainstream approach.

Table 1 . The main services that are provided by the e-Government

\begin{tabular}{|c|c|}
\hline e-Government used services & $\%$ \\
\hline Information about checking traffic tickets & 81.3 \\
\hline Information about the weather & 51.1 \\
\hline Renew passport & 39.4 \\
\hline Renew ID card & 28.4 \\
\hline renew a driver's license & 18.9 \\
\hline Paying bills & 17.2 \\
\hline Information about car tax & 16.8 \\
\hline Apply for job & 10.1 \\
\hline Renew health card & 8.1 \\
\hline Pay taxes & 7.9 \\
\hline Tax refund & 7.3 \\
\hline Income tax settlement & 7.1 \\
\hline Tax situation & 6.5 \\
\hline Renew family document & 1.6 \\
\hline
\end{tabular}

*(AlJaghoub et al., 2010) 
Many of the actual users of the services are very interested in having an Internet-based delivery system from the e-Government in Jordan; Al-Jaghoub et al. (2010) have explained the main services that are provided by the e-Government (Table 1).

\section{3. e-Government}

According to the World Bank's e-Government website, "e-Government” refers to the use by government agencies of information technologies (such as Wide Area Networks, the Internet, and mobile computing) that have the ability to transform relations with citizens, businesses, and other arms of government. These technologies can serve a variety of different ends: better delivery of government services to citizens, improved interactions with business and industry, citizen empowerment through access to information, or more efficient government management. The resulting benefits can be less corruption, increased transparency, greater convenience, revenue growth, and/or cost reductions.

Government services are provided through a variety of channels including retailers, banks and post offices. It is critical that the technology solutions which sit on top of an e-Government infrastructure are within the reach of all citizens. Successful e-government should be able to: attract citizens who are already connected online; move people online who are not already there; and enable the transformation to e-government at three levels: government-to-government (G2G), government-to-business (G2B), and government-to-citizen (G2C). (Reffat, 2006)

These user categories include nationals as well as foreigners, investors and others with interest in Jordan. (National ICT Strategy of Jordan 2007-201, e-Government will, among other things, contribute to improving:

- $\quad$ Citizens' opportunities for social developments.

- Governments' openness, effectiveness and efficiency in serving citizens and businesses, as well as governmental efforts related to financial reforms and skill development for public sector employees.

- $\quad$ Businesses' ability to innovate, invest and grow in an environment that is transparent, less costly to do business and less bureaucratic. (Jordan e-Government Program, e-Government Strategy).

\section{4. e-Government in Jordan}

Jordan's national e-government program was launched by his Majesty King Abdullah II the King of Jordan in September 2001. According to the official site of the Jordanian e-Government, the vision of the program is "An essential and active participant in the economic and social development through the use of information and communication technology to enable easy access to government information and services for all Users regardless of their geographic location or economic status or professional capacity".

Jordan as numerous of the Medill East countries is an evolving country in the Middle East with a community of about 6,289,053 at the starting of the 2012 year with very restricted natural resources. The e-Government start in Jordan has been one of a number 
of ICT associated initiatives commenced with the progression of monarch Abdullah II to the throne in 1999, the aim of which is to change the country into a knowledge-based finance (Al-Jaghoub and Westrup, 2003). Jordan's nationwide e-Government program aspires to provide government and agencies services all through diverse electrical devices passages such as internet, SMS gate, and posted letters. The e-Government program aspires to consign high-quality services to buyers, businesses and organizations; advance government performance and efficiency; enhance Jordan's competitiveness; double-check public part transparency and responsibility; reduce costs and alleviate of interaction with government; encourage development of Jordan's ICT part; develop skills inside the public part; increase e commerce undertakings; and advance information security.

\section{5. e-Government Development in Jordan (Readiness)}

Technology readiness can be explained as technology infrastructure and IT human resources.

Technology readiness "is reflected not only by physical assets, but also by human resources that are complementary to physical assets” (Mata et al. 1995). Technology infrastructure establishes a stage on which internet technologies can be built; IT human resources provide the knowledge and skills to develop web applications (Zhu and Kraemer 2005). Theoretical assertions are supported by a number of empirical studies (Armstrong and Sambamurthy 1999, Hong and Zhu 2006, Iacovou et al. 1995, Pan and Jang 2008).

According to the United Nations e-government survey, 2010; 'e-government development', replaces the term 'e-government readiness'. The term 'e-government development' describes how far governments have actually advanced in this field instead of how ready or able they might be to do so, which was how the 'e-government readiness' described national capacity. More countries than ever before are adopting national e-government strategies and multi-year action plans. From the most to the less developed, countries can be seen responding to expectations that governments both participate in and enable the information society by communicating and interacting more effectively with increasingly technology-savvy citizens. They are ready, and it is their level of development in this regard that must be assessed.

The UN Report (2010) global e-government development ranked Jordan as number 51 with an index of 0.5278 out of 1.0000 around the world, with slight retardation in its ranking from 2008 survey to that survey conducted in 2010 (Table 2). 
Table 2. Top ranked developed countries in e-Government development index, UN Report (2010)

\begin{tabular}{|c|c|c|c|c|c|}
\hline \multirow[b]{2}{*}{ Rank } & \multirow[b]{2}{*}{ country } & \multicolumn{2}{|c|}{ 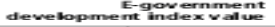 } & \multicolumn{2}{|c|}{$\begin{array}{l}\text { Morkd e-gonernisent } \\
\text { developmemt ranking }\end{array}$} \\
\hline & & 2010 & 2008 & 2010 & 2008 \\
\hline 1 & Republic of Korea & 0.8785 & 0.8317 & 1 & 6 \\
\hline 2 & Singapore & 0.7476 & 0.7009 & 11 & 23 \\
\hline 3 & Bahrain & 0.7363 & 0.5723 & 13 & 42 \\
\hline 4 & Israel & 0.6552 & 0.7393 & 26 & 17 \\
\hline 5 & Colambia & 0.6125 & 0.5317 & 31 & 52 \\
\hline 6 & Malaysia & 0.6101 & 0.6063 & 32 & 34 \\
\hline 7 & Chile & 0.6014 & 0.5819 & 34 & 40 \\
\hline 8 & Uruguay & 0.5848 & 0.5645 & 36 & 48 \\
\hline 9 & Barbadas & 0.5714 & 0.5667 & 40 & 46 \\
\hline 10 & Cyprus & 0.5705 & 0.6019 & 42 & 35 \\
\hline 11 & Kazakhstan & 0.5578 & 0.4743 & 46 & 81 \\
\hline 12 & Argentina & 0.5467 & 0.5844 & 48 & 39 \\
\hline 13 & UnitedArab Emirates & 0.5349 & 0.6301 & 49 & 32 \\
\hline 14 & Kumait & 0.5290 & 0.5202 & 50 & 57 \\
\hline 15 & sordan & 0.5278 & 0.5480 & 51 & 50 \\
\hline 16 & Mangolia & 0.5243 & 0.4735 & 53 & 82 \\
\hline 17 & Ukraine & 0.5181 & 0.5728 & 54 & 41 \\
\hline 18 & Antigua and Barbuda & 0.5154 & 0.4485 & 55 & 95 \\
\hline 19 & Mexico & 0.5150 & 0.5893 & 56 & 37 \\
\hline 20 & Saudi Arabia & 0.5142 & 0.4935 & 58 & 70 \\
\hline 21 & Russian Federation & 0.5136 & 0.5120 & 59 & $\infty$ \\
\hline 22 & Brazil & 0.5005 & 0.5679 & 61 & 45 \\
\hline 23 & Qatar & 0.4928 & 0.5314 & 62 & 53 \\
\hline 24 & Peru & 0.4923 & 0.5252 & 63 & 55 \\
\hline \multirow[t]{2}{*}{25} & Belarus & 0.4900 & 0.5213 & 64 & 56 \\
\hline & World average & 0.4406 & 0.4514 & & \\
\hline
\end{tabular}

The UN e-government readiness index is composed of three indices (see Table 2): online service component index; telecommunication infrastructure index; and the human capital index. Indeed, Jordan has scored an online service component index of 0.1813 (out of 1.0000), which mainly reflects the level of services provided by the Jordanian government through its web sites. The more number of services provided by these sites, the higher score of web measure index will be attained. In other ways, the more advanced services provided by these sites, the higher score of web measure index will be attained. In short, this index generally reflects the content and delivery of e-government services.

Whereas, the telecommunication infrastructure index reflects the degree to which a country is prepared for e-transformation and e-delivery. Jordan has scored a telecommunication infrastructure index of 0.0596 (out of 1.0000), which reflects a very basic level of its e-development especially the technological infrastructure.

The human capital index reflects the degree to which citizens are prepared to participate in the networked world. Jordan has scored a human capital index of 0.2869 (out of 1.0000), which reflects good enough impression about citizens awareness of e-government services in Jordan. This index means Jordanian citizens advances would not be an issue of debate. In conclusion, the government of Jordan has recently witnessed significant progress in utilizing ICT in its sectors; high score in the human capital index, considerable score in the online service component index, and more attention should be paid to invest heavily in utilizing the internet technologies for raising the telecommunication infrastructure index.

\section{Previous studies}

Extant literature about e-government emphasizes the implementation and challenges facing it. The following table is a summary of some of the most relevant studies: 
Table 3. Relevant Literature and Findings

\begin{tabular}{|c|c|}
\hline Fin & Sou \\
\hline $\begin{array}{l}\text { Jordan as other developing countries is facing the challenge of implementing } \\
\text { e-government initiatives successfully, This is due to number of factors: } \\
\text { Bureaucracy, lack of accountability \& transparency, and lack of citizen } \\
\text { participation in democratic institutions \& processes. } \\
\text { However, findings indicate Jordan is still far behind some from utilizing ICTs in } \\
\text { delivering government services and information online on one hand. But this } \\
\text { not necessarily means that the Jordanian e-government program is condemned } \\
\text { to failure. } \\
\text { On the other bright side, the review indicates Jordan never seems to lack the } \\
\text { fundamental resources. }\end{array}$ & $\begin{array}{l}\text { Yousef, et al. (2008), } \\
\text { "e-Government } \\
\text { Jordan: In } \\
\text { challenges } \\
\text { opportunities", working } \\
\text { paper, University of } \\
\text { Bradford, UK. }\end{array}$ \\
\hline $\begin{array}{l}\text { Building an information based society has become a priority in Jordan, this was } \\
\text { using following several strategies such as developing ICT infrastructure, human } \\
\text { resources, legislations and other entities to reach the required success,. } \\
\text { Jordan has many obstacles facing its implementation of e-government program } \\
\text { summarized as follows: } \\
\text { Digital gap between communities, lack of national policies regarding science } \\
\text { and technology, lack of organizational and legislation laws, lack of sufficient } \\
\text { ICT applications, the existence of technological illiteracy, lack of proper } \\
\text { funding, and lack of experienced workforce. }\end{array}$ & $\begin{array}{l}\text { Eman, N. Mohammad } \\
\text { H. } \\
\text { "Computerization and } \\
\text { e-Government } \\
\text { implementation } \\
\text { Jordan: Challenges, } \\
\text { obstacles and successes", } \\
\text { Government Information } \\
\text { Quarterly 26, 577-583. }\end{array}$ \\
\hline $\begin{array}{l}\text { e-Government implementation in Jordan suffers from internal and external } \\
\text { barriers; The internal challenges are involved ensuring better understanding to a } \\
\text { common vision to e-government and providing leadership at many levels to } \\
\text { translate vision into actions where the leaders should learn how to support } \\
\text { agencies in the e-government implementation, so there is a need for cooperation } \\
\text { to ensure interoperability, avoid duplicate services to ensure that the } \\
\text { government officials have tools to do their mission, to monitor and evaluate } \\
\text { success. } \\
\text { Government face external challenges: The rapid changes in technology and the } \\
\text { other challenges in people who do not have PCs or have access to the internet, } \\
\text { and people who use the online services need a guarantee of privacy and security } \\
\text { where the information provided will not be misused. } \\
\text { The success of e-government process is highly dependent on legal framework } \\
\text { for their operations. }\end{array}$ & $\begin{array}{l}\text { Heba, M. Tamara, M. } \\
\text { Amer, A. (2009), } \\
\text { "E-Government in } \\
\text { Jordan", working paper, } \\
\text { European Journal of } \\
\text { Scientific Research, } \\
\text { Vol.35 No.2 (2009), } \\
\text { pp.188-197. }\end{array}$ \\
\hline $\begin{array}{l}\text { Challenges faces the implementation of e-government initiatives in Jordan } \\
\text { summarized in: } \\
\text { - Low level of Internet penetration } \\
\text { - The relatively high cost of Internet access and } \\
\text { telecommunications services }\end{array}$ & $\begin{array}{l}\text { Alomari, H. (2006)," } \\
\text { E-Government } \\
\text { Architecture In Jordan: A } \\
\text { Comparative Analysis", } \\
\text { Journal of Computer } \\
\text { Science, Vol. 2, Issue 11, }\end{array}$ \\
\hline
\end{tabular}




\begin{tabular}{|c|c|}
\hline $\begin{array}{l}\text { - Infrastructure constraints which include high cost of } \\
\text { telecommunications services and lack of adequate civilian } \\
\text { telecommunications "backbone” network nationwide. } \\
\text { - Digital Divide: a digital exists in terms of geography, } \\
\text { age, skills, gender and income. } \\
\text { - Privacy versus security concerns: legitimate concerns about } \\
\text { the citizens' rights to privacy versus the state's national } \\
\text { security concerns. } \\
\text { Limited Information Technology IT skills: There is a lack of computer } \\
\text { literacy in Jordan which limits s the participation of citizens, } \\
\text { businesses and government institutions. } \\
\text { Limited public sector reform efforts: mean that e-Government } \\
\text { initiatives need to be tightly focused on specific service areas. } \\
\text { Lack of legal framework and adequate legislations. } \\
\text { - Lack of awareness about e-government between general population } \\
\text { and business sectors. }\end{array}$ & $\begin{array}{l}\text { pp. 846-852. } \\
\text { Elsheikh, Y, Cullen, A } \\
\text { and Hobbs, D. (2008), " } \\
\text { e-Government in Jordan: } \\
\text { Challenges and } \\
\text { Opportunities”, } \\
\text { Transforming } \\
\text { Government: People, } \\
\text { Process and Policy, Vol. } \\
\text { 2, No.2, pp. 83-103. }\end{array}$ \\
\hline $\begin{array}{l}\text { Literature and theoretical analysis offered various factors that influence } \\
\text { e-government under the broad themes summarized in: Political, social, } \\
\text { technological and organizational contexts, these themes can be synthesized and } \\
\text { captured in a conceptual model as key factors that need to be considered when } \\
\text { studying e-government and its barriers to implementation. }\end{array}$ & $\begin{array}{l}\text { Vishanth, W. Ramzi, E, } \\
\text { Shafi, S. (2010), } \\
\text { "Exploring } \\
\text { complexities } \\
\text { e-government } \\
\text { implementation and } \\
\text { diffusion in a developing } \\
\text { country, some lessons } \\
\text { from the state of Qatar", } \\
\text { research paper, Journal } \\
\text { of Enterprise Information } \\
\text { Management, Vol.24 } \\
\text { No.2 (2011), pp.172-196. }\end{array}$ \\
\hline
\end{tabular}

\section{Challenges for e-Government Implementation and Diffusion}

The rapid growth of the internet and the vast success of e-commerce within the last few years have resulted in a strong influence not only to the private sector but also to the public sector in Jordan. Governments accordingly started to harness ICT to improve their performance and to achieve what was considered to be beyond their expectations. E-Government has become the effective tool to modernize Jordanian public administration, which, is organized in a bureaucratic hierarchy. Al-Sobhi et al (2010) explain e-government diffusion and adoption "a global topic that concerns many developed and developing countries worldwide”. The global efforts to provide e-services to different stakeholders differ from one country to another in conditions of readiness, challenges, adoptions, and diffusions, these differences are due to the difference of technological, political, cultural, economic, and social differences (Al-Sobhi et 
al, 2010), However, success of e-government programs differs quite considerably depending on the context within which they are developed and implemented. Challenges may face implementing of e-government in any country, those might varies in priority and importance for implementation, some of them seems to be very basic others are more advanced and complicated, regardless of the nature of the point and the importance for implementation, a multidimensional and an interrelationship between these points exist. (Bonham, 2001)

An examination of the e-government literature reveals that although different researchers have identified different factors that influence e-government implementation and diffusion, these factors can be broadly classified under four headings; political factors, social factors, technological factors, and organizational factors. (Vishanth et al., 2010).

\section{1- Political factors:}

A multilayered challenge for the development of e-government is government, information technology, management, and funding. The success of e-government initiatives and processes are highly dependent on government's role and support in ensuring a proper legal framework for their operation. The introduction and uptake of e-government services and processes will remain minimal without a legal equivalence between digital and paper processes.

A common vision is essential to e-government as a means to engage and co-ordinate agencies. It also serves to engage political leaders and to impress upon them the importance of e-government. A common vision is not a goal in itself, but a means to achieve policy priorities. (Edwin, 2003).

Implementation of e-Government not only requires the deep commitment of top management but also requires huge capital investment and operational expenditures. Public sectors organizations generally show resistance in the huge financial investment to initiate e-Government projects. In first study the top leadership shows enthusiasm and initiatives in the implementation of e-Government due to external availability of funds but gradually they lose their interest due to lack of available financial resources. Organization delayed project due to financial limitation and bureaucratic procedures. The involvement of top leadership in the implementation of all stages of e-Government is necessary. (Nasim and Hafez, 2010).

\section{2- Social factors}

Social issues are concerned with the usability by a large variety of people, this implies that the interface should be usable by for example people with special needs, elderly people, low literacy or non-native language people, etc. The general population, government and business sectors currently have a very limited idea about what e-government is and how to benefit from it. This could be a big challenge for Jordan to move ahead in building a successful model of e-government. (Yousef et al., 2008).

ICT-related skills are important not just for ICT production and service industries, but for the economy as a whole. ICT skills have become a new general skill, like literacy or numeracy, and governments have to implement a range of policies to promote the acquisition of basic and advanced needs skills (Edwin, 2003).

The digital divide is an important barrier to e-government, in that people who do not have 
access to the Internet will be unable to benefit from online services. Many developing countries suffer from the digital divide, and they are not able to deploy the appropriate ICT infrastructure for e-Government deployment. (World Bank, 2003).

\section{3- Technological factors}

ICT infrastructure is recognized to be one of the main challenges for e-Government. Internetworking is required to enable appropriate sharing of information and open up new channels for communication and delivery of new services. (Valentina, 2004). For a transition to electronic government, architecture, that is, a guiding set of principles, models and standards, is needed. (World Bank, 2003). It is common for different government agencies to have different hardware and software that may network, integrate and interoperate together; this may lead to e-government implementation difficulties. Also, it requires participating government agencies to share their data to serve and achieve citizens' or e-government system users' needs. Therefore, information technology standards are needed to avoid any hardware and system barriers that would hinder the implementation of e-government systems. (Vishanth et al., 2010).

When talking about technological challenges, one of the most significant challenges for implementing e-government initiatives is computer security. The U.S Government Accountability Office (GAO) has identified six areas of weakness: security program management, access controls, software development and change controls, segregation of duties, operating systems controls, and service continuity. For e-government activities, service continuity is critical not only for the availability and delivery of services, but also to build citizen confidence and trust (Alomari et al., 2012). However, the risks of fraud and misuse of sensitive data are concerns as well. Privacy also presents a challenge to the implementation and acceptance of e-government initiatives. Concerns about sharing information between agencies (computer matching), and the disclosure or mishandling of private information are frequent subjects of debate. (Report for Congress, 2003).

\section{4- Organizational factors}

Organizational challenges facing implementing the e-government could be summarized in having the suitable and supportive management structure (Vishanth et al., 2010), a flexible strategy is needed to meet the evolving needs of citizens, and the future needs should be planned to ensure sustainability of e-government projects. Training of employees leads to successful implementation of e-government, (Sang et al., 2009) which means that lack of training will be a significant challenge.

\section{The Hypothesis}

The e-government framework developed in this study submits that Jordan is implementing e-government with certain capabilities. This implementation influences and is influenced by different related factors. The actual situation of e-government in Jordan is discussed according to related literature (websites, governmental reports, national \& international reports, and related working papers). The e-government implementation in Jordan is facing a number of challenges that hinders its required progress.

Hypothesis: Jordan is a progressive country in the ICT field. The progress, development and strategy for e-Governance in Government organizations are being implemented by the 
government to improve its efficiency and effectiveness.

\section{Methodology}

\subsection{Research Design}

This study used semi-structured interviews and aim assembly discussions. Six governmental organizations and approximately 30 persons participated in individual face to face or telephone meetings and focus assemblies. The bigger set of interviewees minimizes the awkward facts and figure bias that pertains to qualitative studies.

\subsection{Interview Procedure}

Each interview lasted an average of between 30 minutes for interviews and 1 hour for group discussion. The interviews/group discussions were conducted independently, five by a personal meeting and six by phone interview. A notification by phone and email was sent to each interviewee before each interview. During the interview, the participants were presented with one major question; what is the most progress, development and strategy for e-Governance in Government organizations that is being implemented by the government to improve its efficiency and effectiveness? After each challenge was identified, interviewees were asked to explain and elaborate each challenge and to reflect the challenge to their own organization. Consequently, the interviewees were asked to order the challenges according to their perceived level of importance to their organization. Although the numbers of interviewees were not large, the interviews were adequate in terms of detail, thus generated a significant amount of data.

\section{Analysis and Interpretation}

After data collection, the analyses and interpretation of the data that were made with reference to the research problem cited in this paper and in accordance with the objectives of the study and its hypothesis. Common themes and challenges were identified from interview transcripts (See table 4). Two most important CTIs associated challenges were identified.

Table 4. Identified Common themes and challenges

\begin{tabular}{|c|c|}
\hline Factors & Challenges \\
\hline Political & $\begin{array}{l}\text { - Requires the deep commitment of top management } \\
\text { - Requires huge capital investment and operational expenditures } \\
\text { - Organization delayed project due to financial limitation and bureaucratic } \\
\text { procedures }\end{array}$ \\
\hline Social & $\begin{array}{l}\text { - Lack of citizen awareness and participation of the government of Jordan } \\
\text { regarding the successful implementation of e-government } \\
\text { - Internet access }\end{array}$ \\
\hline Technological & $\begin{array}{l}\text { - ICT infrastructure } \\
\text { - Hardware and software interoperation }\end{array}$ \\
\hline Organizational & $\begin{array}{l}\text { - Organization strategy } \\
\text { - Employee training }\end{array}$ \\
\hline
\end{tabular}




\section{Discussion}

As discussed above, analysis of the interviews and focus group discussions identified three primary CTI related challenges: 1) Political, 2) Social 3) data-driven decision making, and 4) Organizational. The challenges also serve as the framework for the recommendations for future research presented below.

Political: Public sectors organizations generally show resistance in the huge financial investment to initiate e-Government projects. The top leadership shows enthusiasm and initiatives in the implementation of e-Government due to external availability of funds but gradually they lose their interest due to lack of available financial resources. The involvement of top leadership in the implementation of all stages of e-Government is necessary. (Nasim and Hafez, 2010).

Social: The digital divide is an important barrier to e-government, in that people who do not have access to the Internet will be unable to benefit from online services. Many developing countries suffer from the digital divide, and they are not able to deploy the appropriate ICT infrastructure for e-Government deployment. (World Bank, 2003). The National ICT Strategy defines three high-level strategic objectives to be achieved by end of 2011, which involve increasing internet penetration in the Jordan from the current $11 \%$ to $50 \%$, but there will still be large numbers who do not.

Technological: Achieve citizens' or e-government system users' needs. Therefore, information technology standards are needed to avoid any hardware and system barriers that would hinder the implementation of e-government systems. (Vishanth et al., 2010). When talking about technological challenges, one of the most significant challenges for implementing e-government initiatives is computer security. For e-government activities, service continuity is critical not only for the availability and delivery of services, but also to build citizen confidence and trust. However, the risks of fraud and misuse of sensitive data are concerns as well. Privacy also presents a challenge to the implementation and acceptance of e-government initiatives. Concerns about sharing information between agencies (computer matching), and the disclosure or mishandling of private information are frequent subjects of debate. (Report for Congress, 2003). Thus, it requires participating government agencies to share their data.

Organizational: The strategy should consider how to restructure existing organizational models, roles, responsibilities, training and employees' needs. (Ebrahim and Irani (2005). Training of employees leads to successful implementation of e-government, (Sang et al., 2009) which means that lack of training will be a significant challenge.

\section{Conclusion}

The analysis recognized a set of significances for e-Government and avenues for future research based on the critical CTIs related challenges identified in this introductory research effort. Four most important implications for IT professionals emerged from the analysis of the identified challenges. These practical implications are: 1) the need to have information strategies, 2) budgeting and planning of IT expenditures, 3) networked governance, and 4) the 
increasing requirement for better monitoring to ensure compliance.

\section{References}

Al-Jaghoub, S, Al-Yaseen, H and Al-Hourani, M. (2010). Evaluation of Awareness and Acceptability of Using e- Government Services in Developing Countries: the Case of Jordan. The Electronic Journal Information Systems Evaluation, 13(1), 1 - 8.

Al-Jaghoub, S. and Westrup, C (2003). Jordan and ICT Led Development: Towards a competition State. Information Technology and People, 16(1), 93-110. http://dx.doi.org/10.1108/09593840310463032

Alomari, H. (2006). E-Government Architecture in Jordan: A Comparative Analysis. Journal of Computer Science, 2(11), 846-852.

Alomari, M, Woods, P and Sandhu, K. (2012). Predictions for e-Government Adoption in Jordan. Information Technology \& People, 25(2), 207-234.

Al-Sobhi, F., Weerakkody, V. and Al-Shafi, S. (2010). The Role of Intermediaries in Facilitating E-Government Diffusion in Saudi Arabia. Proceedings of the E uropean and Mediterranean Conference on Information Systems, pp. 1-17.

Armstrong, C.P. and Sambamurthy, V. (1999). Information technology assimilation in firms: The influence of senior leadership and IT infrastructures. Information Systems Research, 10(4), 304-327. http://dx.doi.org/10.1287/isre.10.4.304

Bonham, M., Seifert, J. and Thorson, S.(2001). The transformational potential of e-government: the role of political leadership. paper presented at the panel on electronic governance and information policy (Panel 9-1) at the $4^{\text {th }}$ Pan-European International Relations Conference of the European Consortium for Political Research, held at the University of Kent at Canterbury, Kent, September 9.

Ebrahim, Z and Irani, Z. (2005). E-government adoption: architecture and barriers. Business Process Management Journal, 11, 589-611. http://dx.doi.org/10.1108/14637150510619902

Edwin, L. (2003). Challenges For e-Government Development. $5^{\text {th }}$ Global Forum on Reinventing Government, Mexico City, 5 November 2003.

Elsheikh, Y, Cullen, A and Hobbs, D. (2008). e-Government in Jordan: Challenges and Opportunities. Transforming Government: People, Process and Policy, 2(2), 83-103.

Eman, N and Mohammad H. (2009).Computerization and e-Government implementation in Jordan: Challenges, obstacles and successes. Government Information Quarterly, 26, 577-583. http://dx.doi.org/10.1016/j.giq.2009.04.003

Heba, M. Tamara, M and Amer, A. (2009). E-Government in Jordan. working paper, European Journal of Scientific Research, 35(2), 188-197. http://go.worldbank.org/M1JHE0Z280 (accessed on August 10, 2012).

http://www.intaj.net (accessed on September 30, 2012). 
http://www.jordan.gov.jo/wps/portal/General/?New_WCM_Context=/wps/wcm/connect/gov/ eGov/Home/e-Government+Program/ (accessed on September 30, 2012).

Hong, W.Y. and Zhu, K. (2006). Migrating to internet-based e-commerce: Factors affecting e-commerce adoption and migration at the firm level. Information \& Management, 43(2), 204-221. http://dx.doi.org/10.1016/j.im.2005.06.003

Iacovou, C.L., Benbasat, I. and Dexter, A.S. (1995). Electronic data interchange and small organizations: Adoption and impact of technology. MIS Quarterly, 19(4), 465-485. http://dx.doi.org/10.2307/249629

Ministry of Information and Communications Technology. Jordan e-Government Program, e-Government Strategy Report.

Mata, F., Fuerst, W. and Barney, J. (1995). Information technology and sustained competitive advantage: A resource-based analysis. MIS Quarterly, 19(4), 487-505. http://dx.doi.org/10.2307/249630

Nasim, Q and Hafez, K. (2010). e-Government Challenges in Public Sector: A case study of Pakistan", International Journal of Computer Science Issues, 7(5), 310-317. National ICT Strategy of Jordan 2007-2011.

NAO. (2002). Government on the Web II, The UK's National Audit Office, London.

Pan, M.J. and Jang, W.Y. (2008). Determinants of the adoption of enterprise resource planning within the technology-organization-environment framework: Taiwan's communications. Journal of Computer Information Systems, 48(3), 94-102.

Reffat, R. (2006). Developing a successful e-government. working paper, University of Sydney, Australia.

Report for Congress. (2003). A Primer on e-Government: Sectors, Stages, Opportunities, and Challenges of Online Governance, Updated January 28, 2003.

Sang, S., Jeong-Dong, L. E. E and Jongsu, L. E. E. (2009). A Study on the Contribution Factors and Challenges to the Implementation of e-Government in Cambodia. Journal of Software, 4, 529. http://dx.doi.org/10.4304/jsw.4.6.529-535

United Nations. (2008). United Nations e-government survey 2008.

United Nations. (2010). United Nations e-government survey 2010.

Valentina, N. (2004). e-Government for Developing Countries: Opportunities And Challenges. The Electronic Journal on Information Systems in Developing Countries, 18(1), 1-124.

Vishanth, W. Ramzi, E. and Shafi, S. (2010).Exploring the complexities of e-government implementation and diffusion in a developing country, some lessons from the state of Qatar", research paper. Journal of Enterprise Information Management, 24(2), 172-196.

www.moict.gov.jo/MOICT/initiative.aspx (accessed on October 24, 2012). 